remarkable one was witnessed in 1883 by Dr. Manuel A. Diez, at that time physician of the military camp at Maracay. A lightning struck a rancho (small country house built of wood and mud, and thatched with straw or large leaves), where a man slept in a hammock, another lay under the hammock on the ground, and three women were busy about the floor; there were also scveral hens and a pig. The man in the hammock did not receive any injury whatever, whilst the other four persons and the animals were killed. As the wooden framework of the house was probably very dry, the man in the hammock was almost isolated; but the other persons and the animals were in direct contact with the floor-in this case the bare ground.

Near Caracas accidents are comparatively rare. Puring all the years of my residence here no more than six have come to my knowledge: in three of them some damage was done to buildings, in two cases large trees were split, and in one (October, 1882) a ploughman was killed while at work in the field, together with his two oxen, his driving-stick (about four yards long, and shod with an iron point) having acted as lightning-conductor.

A. ERNST

Caracas, February 8

\section{Mira Ceti}

WiTh reference to your note on Mira Ceti in NATURE of February 5, I beg to say that I have observed Mira since December 15,1884 , and my observations show that the star reached a maximum on February 4, when $I$ estimated it equal to $\alpha$ Ceti, or about 2.7 magnitude. It remained of the same brightness up to February $\mathrm{I}_{3}$, and has faded very slowly since that date. It was, last night, not much below a Ceti.

Ballysodare, Co. Sligo, Ireland, March 8

$$
\text { J. E. Gorx }
$$

\section{Physical Geography of the Malayan Peninsula}

I HOPE you will give me space in your journal to correct a few errors that have slipped into the letter under this heading in the issue of December 18 (p. 152) by the Rev. J. E. TenisonWoods.

In the first place, there is no fluor-spar in the drift which carries the tin. The stone referred to is rose-quartz, some of which is very beautifully coloured. I have a specimen of it nearly as large as a man's head. It has a specific gravity of $2 \cdot 63$, and hardne:s equal to ordinary white quart $z$, which it will scratch without difficulty.

In the next paragraph Mr. Tenison-Woods says he cannot recall any mines on the eastern slopes of the mountains. This seems extraordinary, as some of the best mines in Kinta are on the eastern slopes of the valley, and I accompanied Mr. TenisonWoods to the Lehat, Pasin, and Papan mining districts, and, with the exception of the Kwala, Diepang, and Gopeng mines, these were the only ones visited by him in Kinta, which were not on the eastern slopes of the valley. Following out the same idea, he says, spealing of the Kinta valley, "The river flows, like the Perak, on the eastern side of the valley." This is also a mistake, for it is decidedly on the western side, and this accounts for the fact mentioned in the next line: "The eastern tributaries are many and important." If the rivers were as stated by the rev. gentleman, this would be nearly impossible. I have taken the opportunity of asking the opinion of the officer in charge of the Kinta district, and he coincides with my view of the position of the river.

The next point on which I cannot agree is that "there is not the slightest sign of any recent upheaval of the coast-line, while the evidence of subsidence is equally absent. A short time ago a boring was made to a depth of 75 feet at Matang (which is the port of Larut), and I made a section from it, which shows that, within quite recent times, an important alteration of level has taken place. The ground at that place is 6 feet above the present high-water mark. Down to a depth of 17 feet from the surface the formation is marine, but below that, bels of sands, clays, and gravels, with leaf-bands and pieces of wood, are met witb, of the same nature as the drift near the hills, and containing a small quantity of fine tin; these beds extend down to a depth of 75 feet, and most probably much further. It therefore appears that there has been a subsidence of at least 75 feet since the formation of the tin-bearing drift of
Larut. An alteration of level of this cxtent must have madc most important geographical changes in the Straits of Malacca, and may help to solve many of the problems connected with the distribution of the flora and fauna of this interesting locality.

The limestone-hill on the eastern side of the Gapis Pass, called Gunong Pondok, is I 800 feet in beight, instead of 400 feet, as stated; and is connected by a ridge with the main range of mountains. A little further on Mr. Tenison Woods says that there are two mountains called Gunong Hijau. This is a very excusable mistake for a stranger to make, for one is Hijau, which means "green," and the one further to the north is Ijoh, which is the name of a palm (Arenga saccharifera). The Kurat river has its source on the former mountain, at the back of the town of Thaipeng. About four years ago I followed the stream from near the summit of Hijau down to the plains.

Perak Museum, Larut, Perak, January 30 L. Wray, Jun.

\section{The Continuity of Protoplasm in Plant Tissue}

THERE is some danger that those who are unable to make a personal examination of the Floridex may be a little mislecl by Mr. Gardiner's remarks thereon in his article on "The Continuity of the Protoplasm in Plant Tissue" (NATURE, vol. xxxi. p. 390). In arguing in support of his own view that this continuity is not direct, but indirect he states that "Schmitz has found that a pit-closing membrane," "perforated in a sieve-like manner," exists in the Floridex, and that he himself has "been able to confirm Schmitz's results as to the existence of the closing membrane in question."

Now, if Mr. Gardiner means by this that what he terms a pitclosing membrane, perforated in a sieve-like manner, is present in al! the Floridex, or even in all parts of the thallus of a single species, I venture to submit that the statement is not in strict acc rdance with fact. In my investigations into the histology of these plants, special attention was paid to this point, and by no methods that I could devise, or learn from other workers, was such a membrane to be demonstrated in the simpler forms, a', for example, in Petrocelis cruenta. Indeed, I cannot conceive how a sieve-plate arrangement could possibly exist, where the continuity is maintained by a single thread of protoplasm, and that of st:ch extreme tenuity as in the species referred to. So far as I am aware, no one maintains the existence of a sieveplate in the threads of Volvox, and I fail to see why it should be assumed to exist in the equally fine threads now under considera tion.

Further, in Polysiphonia, Ptilota, and other genera, where a membrane is normally present, it is not met with in every fart of the thallus, being absent from the younger portions. In these portions the connecting threads are single and exirenely delicate, so that while observation affords no indication of a sieve-plate, the arrangements themselves preclude the possibility of one. As the threads grow older and thicker, a membrane which may be perforated is developed, but it is no part of the primary wall of the protoplast. Thus, while the connecting protoplasmic threads exist from the first, the so-called pit-closing membran arises as a later development, and is therefore subsidiary to the continuity, and not essentinl to it.

So far, then, as the Floridex are concerned, I think we must recognise two conditions or stages of continuity ; first, a direct continuty, permancnt in the simpler forms, but transitory in the mote complex ones; and second, an indirect continuity, absent from the younger, but present in the older tissues.

Harrogate, March 7

THOMas Hick

\section{Time in the United States}

IN your issuc of January 23 the statement (p. 277) that "local time throughout the United States, as opposed to railway time, has been abolished," is not quite accurate. At the introduction of the "standard" lime an attempt was made in many places to do this, but it has proved impracticable, except near the meridians of time. At other places the local time still governs all the daily business, except what involves travelling. For this the difference, a constant quantity, is romembered, and the proper allowance made. For example, here we allow thirtythree minutes, being west of the meridian of eastern time to that amount.

Akron, Ohio 